\title{
Stage 0a Penile Cancer AJCC v8
}

National Cancer Institute

\section{Source}

National Cancer Institute. Stage Oa Penile Cancer A/CC v8. NCI Thesaurus. Code C140078.

Stage Oa includes: Ta, NO, MO. Ta: Penile cancer with a finding of noninvasive localized squamous cell carcinoma. N0: No lymph node metastasis. M0: No distant metastasis. (AJCC 8th ed.) 